\title{
Biogeography of the Barents Sea benthos
}

\author{
I.A. Jirkov \\ Department of Hydrobiology, Moscow Lomonosov State University, 119899, Moscow, Russia. \\ e-mail:ampharete@yandex.ru
}

\begin{abstract}
Since the mid-19 $9^{\text {th }}$ century, the biogeographical boundary of the Arctic has been drawn through the Barents Sea. Nevertheless, there is still no general consensus on its position, or what an Arctic species is. This is both because of the use of differences in criteria for drawing the biogeographical boundaries and the lack of data on species distribution in the region. Initial schemes were constrained by being based upon abiotic factors in determining the position of boundaries. A detailed chorological analysis, based mainly on polychaetous ranges, shows that within the Sea, the ranges of different groups of species are complementary to each other like parts of jigsaw puzzle. And the real pattern of species distribution differs from the simple scheme dividing the Barents Sea into Arctic and boreal sublittoral regions. For example, some Arctic species are distributed within the Barents Sea in a very similar manner to boreal ones. The distribution of some (shelf) Arctic species within the Barents Sea is indistinguishable from that of some Arctic-Pacific (i.e. arctoboreal) species. The distribution of deep-sea and eurybathic species in the Barents Sea is complementary to distribution of shelf species and this phenomena does not connect with depth. Species entering the Barents Sea from the southwest ("boreal" species) are not a homogenous group as well as "arctic" species. Boreal species can be splitted into at least into inshore species inhabiting tidally mixed inshore water masses and outer shelf species inhabiting stratified shelf water masses. The latter, in their turn, also can be divided into several groups with different ranges within the Barents Sea. A scheme of biogeographical regionalization of the Barents Sea is proposed, based exclusively on chorological data. This scheme differs drastically from the earlier published ones. The main differences are: (1) species range typification has been made on the base of species distribution within the Barentz Sea only, instead of the whole World Ocean; (2) the fauna has been splitted in nine biogeographic groups instead of usual three (arctic, boreal and arcto-boreal).
\end{abstract}

KEY WORDS: biogeography, the North Polar Basin, the Barents sea, Arctic, Polychaeta.

\section{Биогеография бентоса Баренцева моря}

\section{И.А. Жирков}

Кафедра гидробиологии, Биологический факультет, Московский государственный университет имени М.В. Ломоносова, 119899, Москва, Россия.e-mail: ampharete@yandex.ru

PЕЗЮМЕ: С середины XIX в. биогеографическую границу Арктики проводят через Баренцево море. Тем не менее, до сих пор нет согласия в положении этой границы или в том, что такое арктический вид. Такая ситуация возникла как из-за использования разных критериев для проведения биогеографических границ, так и из-за недостатка данных по распространению видов в данном регионе. Положение биогеографических границ в первоначальных схемах было основано на абиотических факторах. Детальный хорологический анализ, основанный в основном на ареалах полихет, показал, что в 
пределах Баренцева моря распространение различных групп видов комплементарно как части пазла. Реальная картина распространения видов отличается от простой схемы, делящей Баренцево море на арктический и бореальный сублиторальный районы. Например, некоторые арктические виды распространены в Баренцевом море весьма сходно с бореальными. Распространение некоторых (шельфовых) арктических видов в пределах Баренцева моря неотличимо от распространения некоторых аркто-тихоокеанских (т.е. аркто-бореальных) видов. Распространение эврибатных видов в Баренцевом море комплементарно распространению шельфовых и этот феномен не связан с глубинами. Виды, проникающие в Баренцево море с югозапада (“бореальные” виды) не являются гомогенной группой, так же как и “арктические” виды. Бореальные виды могут быть разделены по крайней мере на прибрежные виды, населяющие прибрежные водные массы (между прибрежным фронтом и берегом) и виды внешнего шельфа, населяющие стратифицированные шельфовые водные массы. Последние, в свою очередь, также могут быть разделены на несколько групп с разным распространением в пределах Баренцева моря. Предложена схема биогеографического районирования, основанная исключительно на хорологических данных. Эта схема кардинально отлична от ранее опубликованных. Главные её отличия: (1) типизация распространения видов проведена на основе распространения видов в пределах Баренцева моря, вместо всего Мирового океана; (2) фауна была разделена на девять биогеографических групп вместо обычных трёх (арктические, бореальные и аркто-бореальные).

КЛЮЧЕВЫЕ СЛОВА: биогеография, Северный Ледовитый океан, Баренцево море, Арктика, Polychaeta.

\section{What is an Arctic species}

Two groups of criteria, geographic and autecological, have been initially used for designating a species as "Arctic".

Geographic criteria separate Arctic and nonArctic territories or water areas based on:

1. Geomorphology as synonym of the Arctic Ocean, however, some authors include the Norwegian and Greenland Seas in the 'Arctic', but some do not.

2. Geophysical, such as north of the Arctic Circle, $66^{\circ} 33^{\prime} \mathrm{N}$ (Wikipedia). This was adopted as the boundary by some authors of the "Arctic Fauna" series (Schmidt, 1904).

3. Thermal indicators, the boundary is drawn, on land along the $10^{\circ}$ isotherm and at sea along the $5^{\circ}$ isotherm in surface water in July. This boundary passes approximately along $70^{\circ} \mathrm{N}$ on continents (except for southern Greenland, Labrador Peninsula and adjacent areas of the Atlantic, where it descends southward). In the Atlantic, the southern boundary of the Arctic is drawn approximately along the mean position of the Arctic front. Within this concept, the Arctic includes almost the entire Arctic Ocean (except for the eastern and southern Norwegian Sea) with all its islands (except for islands of Norway), as well as adjacent areas of the Atlantic and the Pacific (Wikipedia).

Autecological criteria are based on the species thermopathy (cold water species as distinct from cold-temperate or temperate). Initial biogeographical schemes, published in European literature, used "boreal": (i.e., northern) for northern Europe, including Scandinavia. Everything further north was usually called "Arctic". The author of one of the first (1837) biogeographical schemes, Milne Edwards separated only three regions in Europe: Mediterranean, Celtic, and Scandinavian. 1853 should be regarded as the year of the onset of the biogeographical regionalization of the Arctic since two key works were published in that year (Dana, 1853; Schmarda, 1853). These authors independently supplemented the scheme of Milne Ed- 
wards with the Arctic region. The names "Arctic" and "boreal" became common, and they were already widely accepted at publication of the first worldwide biogeographical scheme of Ortmann (1896). Eight years later, Schmidt (1904) reviewed the biogeography of cold and temperate waters of the North Hemisphere and suggested his own scheme, also using the term "Arctic" but employing "temperate" instead of "boreal".

The authors of the initial schemes had only fragmentary data on the spatial distribution of the biota. Therefore, they used temperature data for extrapolation of the boundary, assigning to the Arctic the areas with temperature lower than a certain arbitrarily chosen value. Dana (1853) assigned to the Arctic Kingdom the waters within the isocrime (the line of mean temperature for the coldest month) of $44^{\circ} \mathrm{F}$ $\left(6.3^{\circ} \mathrm{C}\right)$. This are includes "Norway, Iceland, Greenland, the Alaska Archipelago, and adjoining parts of the coasts of America and Kamchatka" (Dana, 1853: 1554), the Bering Sea, waters around the Aleutian and North Kurile Islands. Ortmann defined the Arctic Region by not only low temperature but also by its high yearly amplitude. He subdivided the Arctic Region into Arctic-Circumpolar and two boreal areas (Atlantic and Pacific), drawing the boundary along the border of floating ice and suggesting that inside that border water has a permanent temperature close to $0^{\circ}$ (actually, sea water of $35 \%$ freezes at $-1.9^{\circ} \mathrm{C}$ ). Schmidt wrote about necessity [to take into account the 3 criteria: 1 ) the general fauna composition; 2) prevailing cold-water forms; 3 ) physical nature of the sea ${ }^{1}$ (Schmidt, 1904: 383). Although Schmidt used the term [general fauna composition], his definition of the Arctic fauna explicitly showed that only the temperature was the basis for the subdivision. This is clearly seen from the statements: [Division into zoogeographical regions should be based on physical-geographical data] (Schmidt, 1904: 372) and [I believe that Arctic fauna is that fauna which is affected for certain part of the year by cooling down to ice formation at the surface, and which adapts to temperatures

${ }^{1}$ Square brackets contain the author's translation of non-English text. close to zero at the bottom] (Schmidt, 1904: 392). Schmidt regarded schemes based mainly faunal composition as flawed: [Gunter was based... more on the fauna composition than on physical-geographical conditions, and therefore his adopted regions are often artificial] (Schmidt, 1904: 374). Schmidt included in his Arctic Region areas where ice sometimes forms (but is not constantly present, as in Ortmann), and the bottom temperature is below $+0.5^{\circ} \mathrm{C}$. This region included the Arctic, except for the southeastern Norwegian and southwestern Barents seas, the West Atlantic to Newfoundland, the northern and western Bering Sea, and the entire Okhotsk Sea. These Arctic boundaries were also accepted by Zenkevitch (1946: 112) and Zernov (1949: 277).

Thus, initially, most authors assigned to the Arctic water areas according to their own threshold values of hydrological parameters. The term "Arctic", as used by Dana, Ortmann, Schmidt, and Möbius, represent very different notions. There is no test to choose the best scheme based on physical-geographical criteria. Strict compliance with hydrological characteristics has led to assignment to the Arctic the water areas inhabited by very different biota. Möbius (1901) in his "Fauna Arctica" accepts as the Arctic Region that part of the ocean where the bottom temperature fluctuates around $0^{\circ}$; towards the equator it descends to increasingly lower depths. The same opinion view was adopted by Sars (1891) and Derjugin (1915: 714).

As biological data accumulated, an increasing number of biologists adopted the opinion of the German physician, writer and amateur zoologist Julius Minding (1808-1850), who suggested that biological regionalization should be made based exclusively on the character of biota distribution, and nothing else. This opinion was shared by the Russian marine biogeographers Beklemishev (1969) and Kafanov et al. (1980). The prevailing indices in biogeography are those based on qualitative data (presence/ absence of a species).

Therefore, the concept of Arctic species is treated in several senses in the literature, and there is no consensus on the use of this term. The 


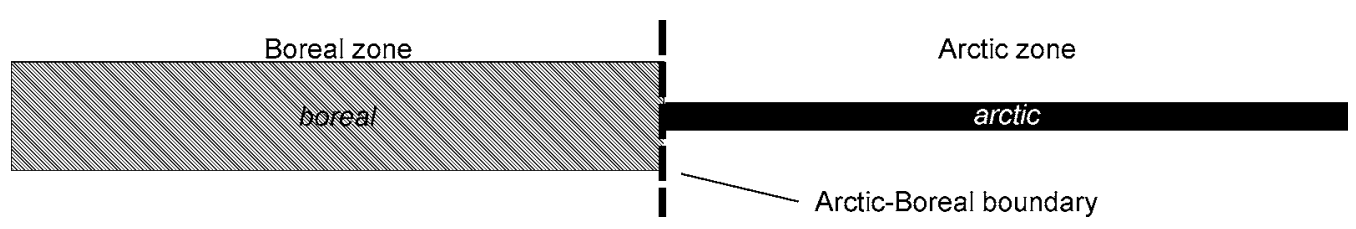

Fig. 1. Scheme explaining terms arctic and boreal.

Different types of species ranges are shown in italic. Width of the horizontal bands reflects number of species with certain type of distribution.

Рис. 1. Схема, объясняющая термины “арктический” и “бореальный”.

Различные типы ареалов показаны курсивом. Ширина горизонтальных полос отражает число видов с данным типом распространения.

using of "Arctic species" has sense if only the author indicates the strict meaning of this term. However, there is the most popular meaning of "Arctic species" which is used in majority of papers and is applied to speices distributed in the shelf. It is widely known that along the northern coast of Europe the species with more southern ranges (boreal) are supplanted with those with ranges situated closer to the Pole (Arctic). The most drastic transition occurs within the Barents Sea.

Usually epithet "Arctic" has been applied to species, inhabiting biogeographic region closest to the North Pole (Fig. 1). As there is wide range of depth within the North Polar Basin species inhabiting deep waters can be found near the North Pole, strictly shelf species cannot be found near the Pole as there is no suitable depth there. Species range of stenobathic deepsea arctic species are quite different from stenobathic shelf ones. To reflect this fact other epithets have been used (shelf, deep-sea, eurybathic). Due the presence of eurybathic species there is no sharp discrimination between deepwater and shelf species, that is why our usage of epithet "Arctic" seems reasonable to apply to deep-water species as well as to shelf ones.

The real pattern of arctic and boreal species distribution is discussed at the end of paper, after detailed consideration of different types of distribution species inhabiting the Barents Sea.

\section{Review of schemes and methods of regionalization of the Barents Sea}

The continental shelf area of the Barents Sea Region has been the subject of biogeographical interest since the development of initial biogeographical schemes. The major published works on marine biogeography, Derjugin (1915), Shorygin (1928), Gurjanova (1951, 1957), Ekman (1953), Filatova (1958), Zenkevitch (1963), Golikov (1963, 1980), Briggs (1974, 1995), Nesis (1982, 1987), Herman (1989), Anisimova (1989, 2000), Golikov, Scarlato (1989), and Petryashov $(1989,2009)$, differ considerably in their approach to biogeographical analysis. Some of these schemes are shown in Fig. 2 and 3. Most authors draw through the Barents Sea a single biogeographical boundary - a part of the boundary between boreal and Arctic biotas. This makes the Barents Sea a good area for resolving both general methodological issues and the longstanding and intricate problem of delimiting the boreal and Arctic faunas.

The Barents Sea is the northernmost of European seas, part of the continental shelf area surrounding the Arctic Ocean. Known in the Middle Ages as the Murman Sea (Murmanskoye Morye), it takes the current name from the Dutch navigator Willem Barents. The Barents Sea is bordered in the West a line joining the Southernmost point of West Spitzbergen to North Cape of Bear Island, through this island to Cape Bull and thence on to North Cape in Norway $\left(27^{\circ} 45^{\prime} \mathrm{E}\right)$. In the Northwest. The Eastern shore of West Spitzbergen, Henlopen Strait up to $80^{\circ}$ lat. North; South and East coasts of North-East Land [island of Nordaustlandet] to Cape Leigh Smith $\left(80^{\circ} 05^{\prime} \mathrm{N} 28^{\circ} 00^{\prime} \mathrm{E}\right)$. In the North. Cape Leigh Smith across the Islands Bolshoy Ostrov (Great Island) [Storøya], Gilles [Kvitøya] and Victoria; Cape Mary Harmsworth (Southwestern extremity of Alexandra Land) along the 
Fig. 2. Selected biogeographical borders in the Barents Sea.

Рис. 2. Некоторые биогеографические границы, проводимые разными авторами в Баренцевом море.
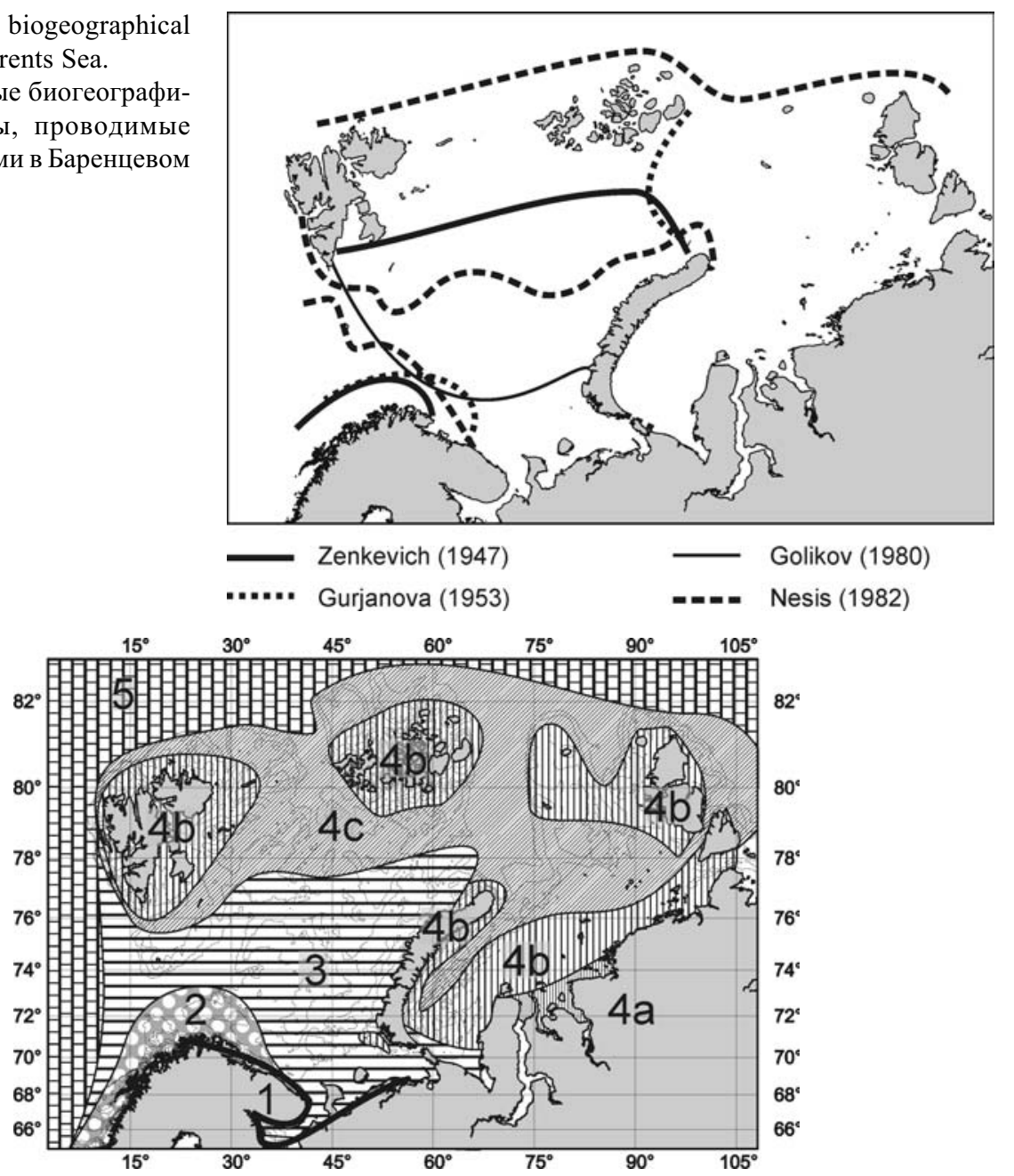

Fig. 3. Scheme of biogeographical regionalization by Z.A. Filatova (1957).

The border and area positions somewhat differ from those illustrated in the paper. They have been corrected according to the text of the paper, where the position of borders and areas were described in detail. The figure published in the paper and the respective text have some discrepancies as concerns the number of biogeographical isolates, not to mention their names, province ranges, and the region subordination.

Boreal Region, north-boreal atlantic Subregion: 1 - Norway-Murman-White-Sea littoral Province; 2 - West-BarentsSea sublittoral Province.

Arctic Region: 3 - low-Arctic sublittoral Subregion, Barents Sea Province; 4 - High-Arctic sublittoral Subregion: $\mathrm{a}$ - Siberian upper-sublittoral brackish-water Province, $\mathrm{b}$ - Siberian-White-Sea sublittoral marine Province, $\mathrm{c}-$ Eurasian marine bathyal Province; 5 - high-Arctic abyssal Polar-Greenland Province.

Рис. 3. Схема биогеографического районирования 3.А. Филатовой (1957).

Границы и положение районов слегка отличаются от данных в её работе, они изменены в соответствии с текстом статьи, где границы и ареалы описаны детально. Опубликованные рисунок и текст несколько различаются также числом биогеографических районов, на орпубликованном ранее рисунке не отражены их ранг и соподчинение. Бореальная область, Северо-бореальная атлантическая подобласть: 1 - Норвежско-Мурманско-Беломорская литоральная провинция, 2 - Западно-Баренцевоморская сублиторальная провинция.

Арктическая область: 3 - Нижнеарктическая подобласть, Баренцевоморская сублиторальная провинция; 4 Высокоарктическая подобласть: а - Сибирская верхнесублиторальная (прибрежная) солоноватоводная провинция, $\mathrm{b}$ - Сибирско-Беломорская сублиторальная морская провинция, с - Евразийская морская батиальная провинция; 5 - Полярно-Гренландская абиссальная провинция. 
northern coasts of Franz-Josef Land as far as Cape Kohlsaat $\left(81^{\circ} 14^{\prime} \mathrm{N} 65^{\circ} 10^{\prime} \mathrm{E}\right)$. In the East. Cape Kohlsaat to Cape Zhelaniya(Desire); West and Southwest coast of Novaya Zemlya to Cape Kussov Noss and thence to Western entrance Cape, Dolgaya Bay $\left(70^{\circ} 15^{\prime} \mathrm{N} 58^{\circ} 25^{\prime} \mathrm{E}\right)$ on Vaigach Island. Through Vaigach Island to Cape Greben; thence to Cape Belyi Noss on the mainland. In the South. a line joining Svyatoi Nos (Murmansk Coast, 39 $47^{\prime}$ E) and Cape Kanin. The Barents Sea is $1,300 \mathrm{~km}$ long and $1,050 \mathrm{~km}$ wide and covers 1.4 million square kilometres. The average depth is $230 \mathrm{~m}$, with a maximum depth of $600 \mathrm{~m}$ in the Bear Island Trench. There are several bank areas, with depths between 50 and $200 \mathrm{~m}$. The eastern corner of the sea, in the region of the Pechora River's estuary, has been known as Pechora Sea.

In earlier works the biogeographical borders were drawn based on several criteria: analysis of biota, hydrological and bathymetric characteristics of relatively large regions, and extrapolation using hydrological data. For example, the map of Schmarda (1853) shows the boundary between the "Arctic Ocean" and "the north of the Atlantic" drawn along the isotherm, although descriptions of biogeographical regions include characteristic animals. Early authors (Schmarda, 1853; Forbes, 1856 and Woodward, 1856) included the entire Barents Sea in the Arctic Region. By the end of $19^{\text {th }}$ century accumulating data led most authors to introduce a transition zone. This zone was called variously: "hyperborean" (Torell), "subarctic" (Packard), "Bore-Arctic" (Appelöf), "lower" (the area of melting drifting ice) as different from "upper" (the area of permanent ice) by Shidlovskiy (after Derjugin, 1915). [Appelöf assigned to the Boreo-Arctic region the ocean area where the water temperature strongly varied, being affected by interchanging warm and cold flows... Here the author includes the coast of eastern Finnmark, the Murman coast, the shallow-water part of the White Sea and the southwestern part of the Barents Sea] (Derjugin, 1915: 715). Derjugin himself preferred the name subarctic Region, reasonably believing that the name "BoreoArctic" is too similar to the type of distribution of taxa occurring in both Arctic and boreal waters. The subarctic Region of Derjugin (1915) [is hydrologically characterized by a near-bottom temperature usually not descending below $0^{\circ}$ and not ascending above $5-6^{\circ} \ldots$ Floating polar ice also usually does not enter these waters] (Derjugin, 1915: 718). Derjugin drew the north boundary of the subarctic Region from the White Sea entrance northwestward towards Bear Island and to southern Spitzbergen along the boundary of the floating ice; the south boundary was drawn through Iceland and the Faeroes.

In the biogeography of the Barents Sea, three different concepts of a biogeographical region have been employed, based on data on species distribution.

In the first case, the water area was divided into regions by studying the species range borders (by range typification, or by finding the species ranges boundaries condensation). Usually the borders of regions were drawn at the same scale as that used at the range typification. The maps used, or the analysis, are of the scale of about 1.5-2.5 million or smaller (they show, for example, the entire Arctic, or temperate and high latitudes of the North Hemisphere). Correspondingly, the borders (Fig. 2) are rough (Zenkevitch, 1947; Gurjanova, 1951; Golikov, 1963, 1980; Nesis, 1982). The main virtue of this method was to provide an easy biogeographical interpretation of the results, because all the borders are biogeographical. An additional advantage is the possibility of small-scale regionalization using a small body of data.

One computers became available, to group the data by different methods, authors began to separate regions by the similarity of species composition, estimated by one or another coefficient (the required similarity value is set subjectively). This understanding of a biogeographical region allows regionalization at any scale, irrespective of the body of data. However, there are problems of biogeographical interpretation because the method does not permit us to distinguish biogeographical borders from those of biocenoses (=communities).

Shorygin (1928) suggested a third concept for a biogeographical region, that [a part of given water basin or area, the fauna of which is 

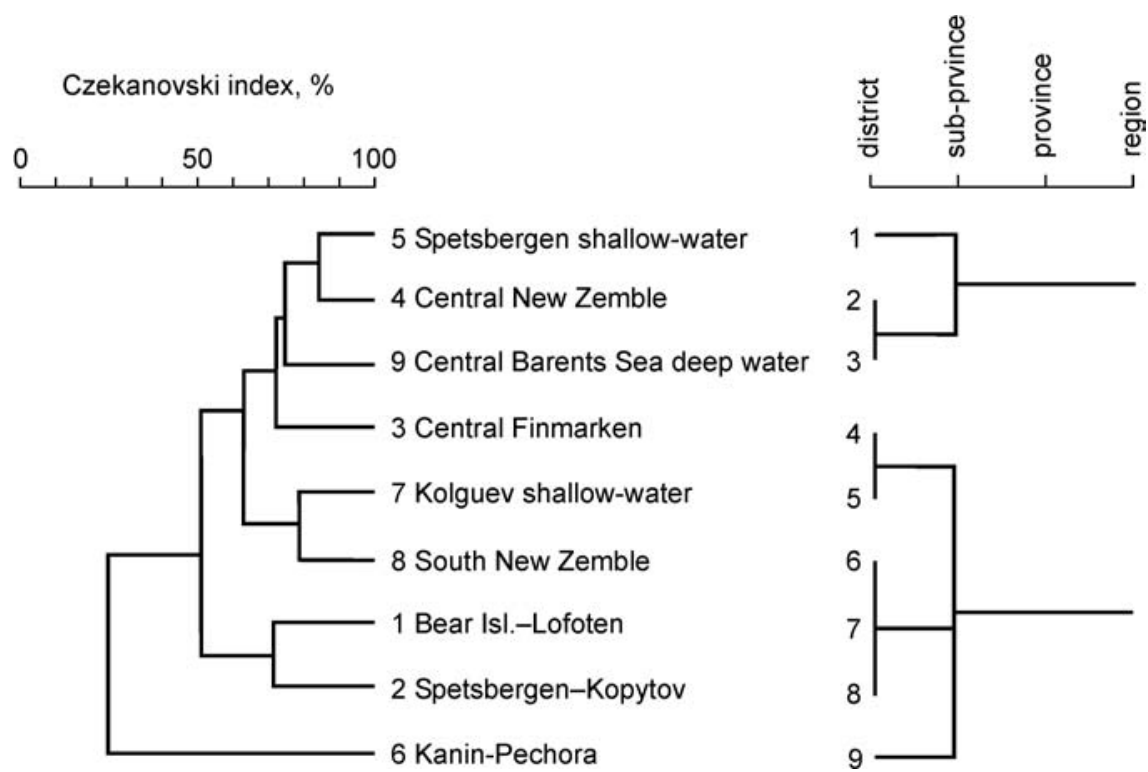

Fig. 4. Comparison of results of region grouping by different methods.

On the left - the results of cluster analysis using the Czekanovski index by percent ratio of species groups of different biogeographical affinity. On the right - group of the same regions based on direct comparison of their species lists. The figures correspond to the same regions. After the data of Anisimova (2000).

Рис. 4. Сравнение результатов группирования районов, проведенного разными методами.

Слева - результаты кластерного анализа с использованием индекса Чекановского по процентному соотношению групп видов разной биогеографической природы. Справа — группировка тех же регионов, основанная на прямом сравнении их фаун. Числами слева и справа обозначены одни и те же регионы.

characterized by prevalence of some zoogeographical element over each of other elements composing the fauna]. (Shorygin, 1928: 100). A scheme of Z.A. Filatova, exemplifying this approach is shown in Fig. 3. This concept of a biogeographical region allows more regions to be isolated than previous methods, with the same body of data. However, there are some shortcomings.

1. The main shortcoming was clear to Shorygin (1928): [zoogeographical groups prevailing over each other, which thus becomes the basis of our concept, are to a certain degree artificial and arbitrary]" (Shorygin, 1928: 100). This is a drawback of the method of typification of ranges, rather than of the Shorygin's method. However, while regionalization by typification of ranges allows us to avoid the discrepancies due to generalization, Shorygin's method leaves less possibility for generalization in determination of biogeographical nature of a region. The typification of ranges can lead to results that cannot be interpreted. A good example of com- pletely different results from the use of the second and third concepts can be seen in Fig. 4, from Anisimova (2000).

2 . The results are very sensitive to subsequent changes in data. For example, of 27 echinoderm species assigned to the Arctic by Shorygin, only 12 are currently considered as such, because other species have been found far outside their previously known range (Jirkov, 2004).

Of the three concepts mentioned, the first, based on studying species range borders, is preferable. Although a range is three-dimensional, it is currently not possible to draw the species range borders in tridimensional space, primarily due to insufficient data. Despite sampling about 10,000 stations have been sampled in the open part of the Barents Sea between 1921-1977 (Alekseeev, Galkin, 1981). Supposing that about the same number of stations have been sampled since then, a single sample is still the basis of judgement on nearly $100 \mathrm{~km}^{2}$ of the bottom area. Moreover, only some species and 
only in areas of their mass development are characterized by incidence of $100 \%$.

It is known that there are no [special scientific or technical means for drawing the species range borders. The species range borders of ranges are drawn by formal connection of extreme points... or by extrapolation] (Tupikova, Komarova, 1979: 154). This widely used method usually results in distorted and reduced species ranges, while the degree of reduction directly depends on the number of collected samples. For the extrapolation data on hydrology usually are used but hydrological maps based on extrapolation of data as well. The positions of usual species range borders are rather well known, whereas the rare species range borders for are drawn approximately. The method of range typification is an extrapolation of poorly known ranges by better-known ones, and the refinement of the biogeographical scheme depends on the number of usual species. However, any [implementation of extrapolation is very rarely based on objective criteria and to a large degree remains intuitive, not no say arbitrary] (Tupikova, Komarova, 1979: 142). Tolmachev (1962: 20, 1974: 30) called the species ranges [arbitrary patterns].

Kuznetsov (1936) studying distrubution of East European mammals has found that their species range borders usually coincide and give a line. He call such a line "synperate". Later several authors (Kiseleva et al., 1969; Razumovsky, 1999) proposed to use for extrapolation of species range borders with similar distribution in a certain place. This metod is used here and resulting species range borders is called "synperate". Thus each synperate is a boundary of distribution of a group of species with one and the same type of range in a certain place. Similar approach has been used by Dice (1943) for delimiting biotic provinces of North America. Based on the similarity of distribution of species within the Barents Sea, several types of local (i.e. within the Barents Sea) species groups (LSGs) were identified. The range borders of species belonging to the same LSG do not coincide completely, but form a crowding zone. So each synperate was drawn along the outer edge of the crowding zone. The group divisions were completely chorological, without regard to data on temperature, depth, bottom type, etc. The latter data were used only in the characterization and description of isolated regions, as well as in description of the position of synperates.

Range borders of certain species, as well as borders of biogeographical regions, can be tortuous, with mosaic patterns occurring. For example, in the Barents Sea, isolated depressions and scoops of the Kola and Motovsky bays are inhabited by relict Arctic fauna with many Arctic and no boreal species. Finding of such refuges is usually possible at a large map scale. At small scale, they make a deceptive appearance of blurred biogeographical borders (Filatova, 1957: 200; Antipova, 2000: 248). So in identifying the LSGs, there was no requirement for range continuity; the range could consist of any number of fragments.

The accuracy in drawing biogeographical borders depends on the number of species used in the analysis and on the number of records of each species. In practice, due usually to insufficient data, there is a tendency for the species range borders to be straightened and the ranges shown as continuous.

The number of polychaete species known in the Barents Sea is high. They are readily sampled by both trawls and dredges and are an appropriate group for biogeographical studies. Recently, taxonomic revisions of the fauna of Russian northern seas, has enabled good identification of some taxa, i.e. more than one third of the Barents Sea polychaete fauna (Uschakov, 1972, 1982; Khlebovich, 1996; Kupriyanova, Jirkov, 1997; Jirkov, 2001).

Large collections of polychaetes from the Barents Sea enable a detailed study of the Barents Sea biota. With this data is not necessary to use hydrological data species ranges (or other biological phenomena) can be studied directly. Although the distribution of the biota depends on hydrology and geomorphology, it would be presumptuous to suggest that, with our current knowledge, we can to point out the characters really important for the ecosystems. In other words, we cannot assume that areas splitted by 
Fig. 5. Map of data used in analysis. 200-m and 500-m isobaths are shown. Not all samples can be found on this and following maps because, in some cases, one location may match several samples as they have been collected close (or even at the same place) and can not be shown as separate sign.

Рис. 5. Карта использованных данных.

Показаны 200 и 500-метровые изобаты. Не все находки отражены на этой и последующих картах, поскольку некоторые были сделаны в одной или близко расположенных точках и не могут быть показаны отдельными значками.

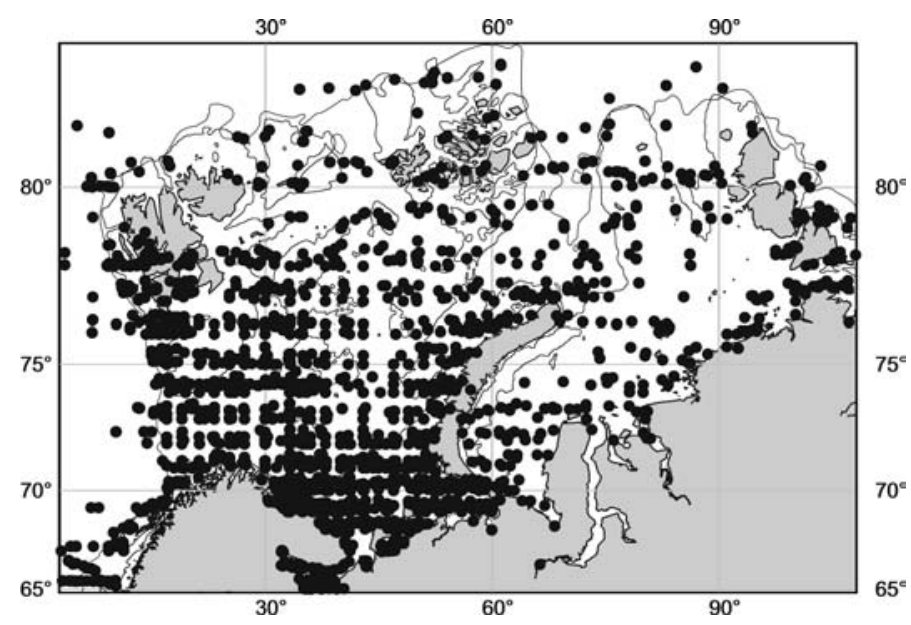

hydrological and geomorphological characters will necessarily coincide with those splitted by species distributions.

The typology of ranges of species found in the North Polar Ocean was developed earlier (Jirkov, 2001; Sirenko et al., 2009), although at the scale of the entire ocean scale or for cold and temperate waters of the North Hemisphere. This study details the analysis of species distribution within the Barents Sea only.

The given maps of LSG show records of several species. Not all of these records can be found on the maps because, in some cases, one location may match several samples collected close to each other. Except for some isolated localities, the extreme points on each map were connected by lines. It should be noted that species within the same LSG could be distributed either similarly or differently outside the Sea. Within the same LSG, species may differ in both the feeding mode and the reproductive mode.

\section{Chorology of polychaetes of the Barents Sea}

\section{Material}

The study was based on the two largest polychaete collections, stored at the ZIN RAS and at the Department of Hydrobiology of MSU. The distribution in the Barents Sea of 157 spe-

cies were studied in the families: Aphroditidae, Sigalionidae, Goniadidae, Nereidae*2, Eunicidae*, Onuphidae*, Chaetopteridae, Flabelligeridae, Scalibregmidae, Maldanidae, Arenicolidae, Pectinariidae*, Ampharetidae*, Terebellidae*, Sabellidae and Serpulidae*. In addition, data was also obtained on the distribution of species from other families, particularly Phyllodocidae. Data of Murmansk Marine Biological Institute (Murmansk) have been used as well. Totally 15912 findings within area shown at figs $5-8,10$ and $12-17$ have been used in analysis (Fig. 5).

\section{Types of polychaetous distribution} within the Barents Sea

Three groups could be identified in respect to their character of geographical distribution within the Sea:

1. Species distributed within tidally mixed regions (shallow-water).

2. Species distributed mainly on the shelf, but not occurring outside it (shelf).

3. Species distributed not only on the shelf but also on adjacent areas of the slope and in the abyssal (eurybathic).

Nine LSGs can be recognized within the Barents Sea. The species within each LGS often

${ }^{2}$ Families marked by an asterisk have been studied in both collections, while the others - only in the collection of the Department of Hydrobiology. 
Table 1. Correspondence between LSG and range types, according to Jirkov (2001), and Sirenko et al. (2009), and commonly used names.

Notes. Sirenko et al. (2009) described only species range, inhabiting either shelf or bathyal and abyssal. There is no any type of species range including both shelf and bathyal-abyssal, despite such ranges are common and numerous among Polychaeta. So correspondence between species ranges of eurybathyc species (our types) and their types is somewhat subjective. One LSG can include species with different distribution outside the Barents Sea.

Таблица 1. Соответствие между местными группами видов (LSG) и типами ареалов по Жиркову (2001), Сиренко и др. (2009) и распространённым пониманием терминов.

Примечания. Сиренко и др. (2009) описали типы ареалов, охватывающих или шельф или батиаль и абиссаль. В их классификации нет типов ареалов, которые охватывали бы и шельф и батиаль-абиссаль, несмотря на то, что такие ареалы обычны и многочисленны среди полихет. Поэтому соответствие между видовыми ареалами эврибатных видов (наши типы) и типами ареалов Сиренко и др. (2009) в определенной степени субъективно. Одна LSG может включать виды с разным распространением за пределами Баренцева моря.

\begin{tabular}{c|l|l|l}
\multirow{2}{*}{ LSG } & \multicolumn{1}{|c}{ Species included in different LSGs or with ranges of different types } \\
\cline { 2 - 4 } LSG-1 & $\begin{array}{l}\text { Shelf and eurybathic Arctic- } \\
\text { Atlantic-Pacific, shelf Arctic-Pacific }\end{array}$ & $\begin{array}{l}\text { Widespread boreal-Arctic (except Pacific } \\
\text { widespread boreal Arctic and Pacific high } \\
\text { boreal Arctic) and subtropical-Arctic }\end{array}$ & $\begin{array}{l}\text { Arctic-boreal and } \\
\text { more widely } \\
\text { distributed }\end{array}$ \\
\hline LSG-2 & Shallow-water Scandinavian & $\begin{array}{l}\text { Atlantic widespread boreal, amphiboreal, } \\
\text { Atlantic subtropical-boreal }\end{array}$ & Boreal \\
\hline LSG-3 & $\begin{array}{l}\text { Shelf near-Atlantic and Atlantic- } \\
\text { Pacific }\end{array}$ & $\begin{array}{l}\text { Arctic, Arctic Eurasian, Pacific } \\
\text { widespread boreal, Pacific high boreal } \\
\text { Arctic }\end{array}$ & Arctic \\
\hline LSG-4 & Arctic bathyal, Arctic bathyal-abyssal & \\
\hline LSG-6 & Deep-sea high-Arctic & $\begin{array}{l}\text { Arctic bathyal, Arctic bathyal-abyssal, } \\
\text { Atlantic-Pacific-Arctic bathyal and } \\
\text { bathyal-abyssal, widespread boreal-Arctic }\end{array}$ & Arctic-boreal and \\
LSG-7 & $\begin{array}{l}\text { Eurybathic pan-Arctic, Arctic- } \\
\text { Atlantic-Pacific, and deep-water } \\
\text { Arctic-Atlantic-Pacific }\end{array}$ & $\begin{array}{l}\text { Arctic bathyal, Arctic bathyal-abyssal, } \\
\text { arcto-Atlantic bathyal and bathyal- } \\
\text { abyssal, Atlantic-Pacific-Arctic bathyal } \\
\text { and bathyal-abyssal, widespread boreal- } \\
\text { Arctic }\end{array}$ & distributed \\
LSG-8 & Eurybathic pan-Arctic & $\begin{array}{l}\text { Atlantic-Pacific-Arctic bathyal and } \\
\text { bathyal-abyssal, widespread boreal-Arctic }\end{array}$ & Boreal \\
\hline LSG-9 & Shelf and eurybathic near-Atlantic
\end{tabular}

differed in their feeding (predators, detritophages, sediment eaters, filter-feeders) and reproductive modes (from species with long-living pelagic larva to those depositing eggs within their tubes and to reproduction by division), so LGS is not ecological groups. Table 1 shows their correspondence to the range names in general use and to the range types compiled by Sirenko et al. (2009) and Jirkov (2001). Species not having range boundaries within the Barents Sea are placed in LSG-1. This group contains many common species that are widely distributed in the Barents Sea. However, this group does not inform us regarding biogeographic regions in the Sea and is not considered further.

LSG-2 includes species living within tidally mixed regions of the south-western part of the Sea (Fig. 6). These are not numerous, although there are more than a dozen in the families considered: Phyllodoce mucosa, Nephtys caeca, Nereis virens, Arenicola marina, Branchiomaldane labradorensis, Pectinaria granulata, P. koreni, Amphitrite figulus, Pomatoceros triquiter, small Sabellidae (Fabricia, Manayunkia) and many Spirorbidae. Among other taxa, this group probably includes Lepidonotus squamatus and Harmothoe viridis, as well as representatives of other classes, including Mytilus edulis, Cerastoderma edule and Asterias rubens. This group should probably be subdivided: one subgroup restricted in its distribution by the northern coasts of the Kola Peninsula, and another, more widely distributed, penetrating in the Pechora Sea and in the in the White Sea. An indicator species of the first subgroup would be Pectinaria granulata. 
Fig. 6. Distribution of LSG-2 species in the Barents Sea.

Shown are 266 findings of Pectinaria granulata and Pomatoceros triquiter.

Рис. 6. Распространение LSG-2 видов в Баренцевом море

Показаны 266 находок Pectinaria granulata и Pomatoceros triquiter.

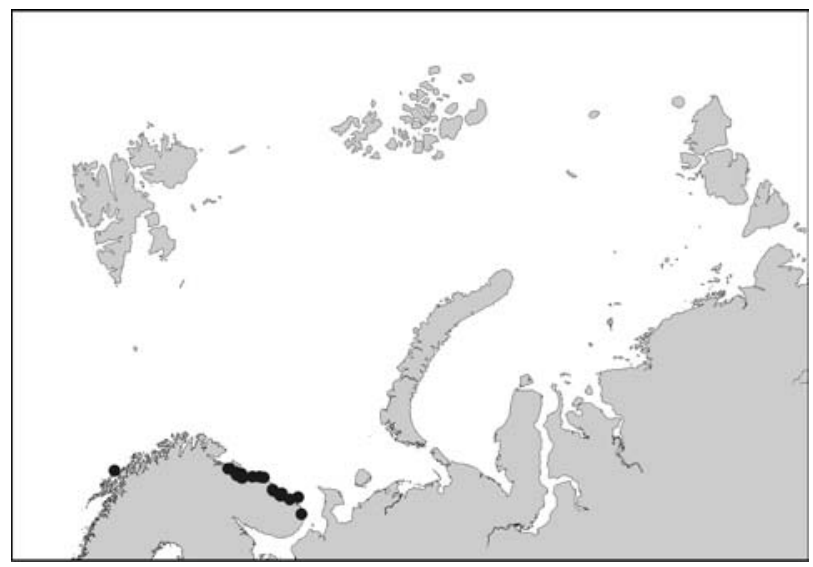

Fig. 7. Distribution of LSG-3 species in the Barents Sea.

Shown are 245 findings of Aphrodita aculeata, Laetmonice filicornis, L. uschakovi, Neoleanira tetragona, Goniada maculata, $G$. norvegica, Hyalinoecia tubicola, Paradiopatra fjiordica, P. quadricuspis, Eunice pennata, Owenia borealis, Pectinaria auricoma, Filograna implexa. 200- and 600-m isobaths are shown.

Рис. 7. Распространение LSG-3 видов в Баренцевом море

Показаны 245 находок Aphrodita aculeata, Laetmonice filicornis, L. uschakovi, Neoleanira tetragona, Goniada maculata, G. norvegica, Hyalinoecia tubicola, Paradiopatra fjiordica, P. quadricuspis, Eunice pennata, Owenia borealis, Pectinaria auricoma. Filograna implexa. Показаны 200- и 600метровые изобаты.

Fig. 8. Distribution of LSG-4 species in the Barents Sea.

Shown are 350 findings of Nephtys longosetosa, Nereis pelagica, Polyphysia crassa, Sosane wireni, Amphitrite groenlandica, Pista bansei, Hydroides norvegica. 200- and 600$\mathrm{m}$ isobaths are shown.

Рис. 8. Распространение LSG-4 видов в Баренцевом море.

Показаны 350 находок Nephtys longosetosa, Nereis pelagica, Polyphysia crassa, Sosane wireni, Amphitrite groenlandica, Pista bansei, Hydroides norvegica. Показаны 200- и 600 -метровые изобаты.
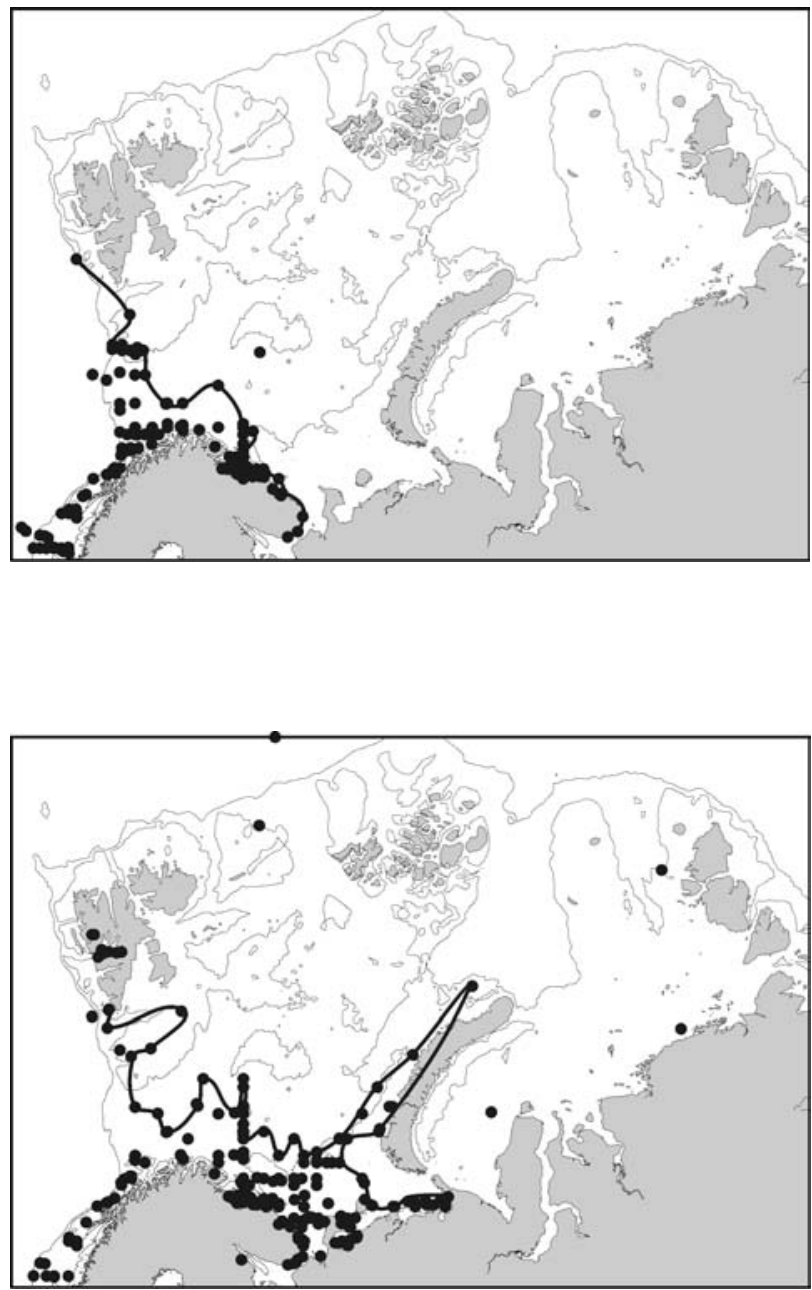

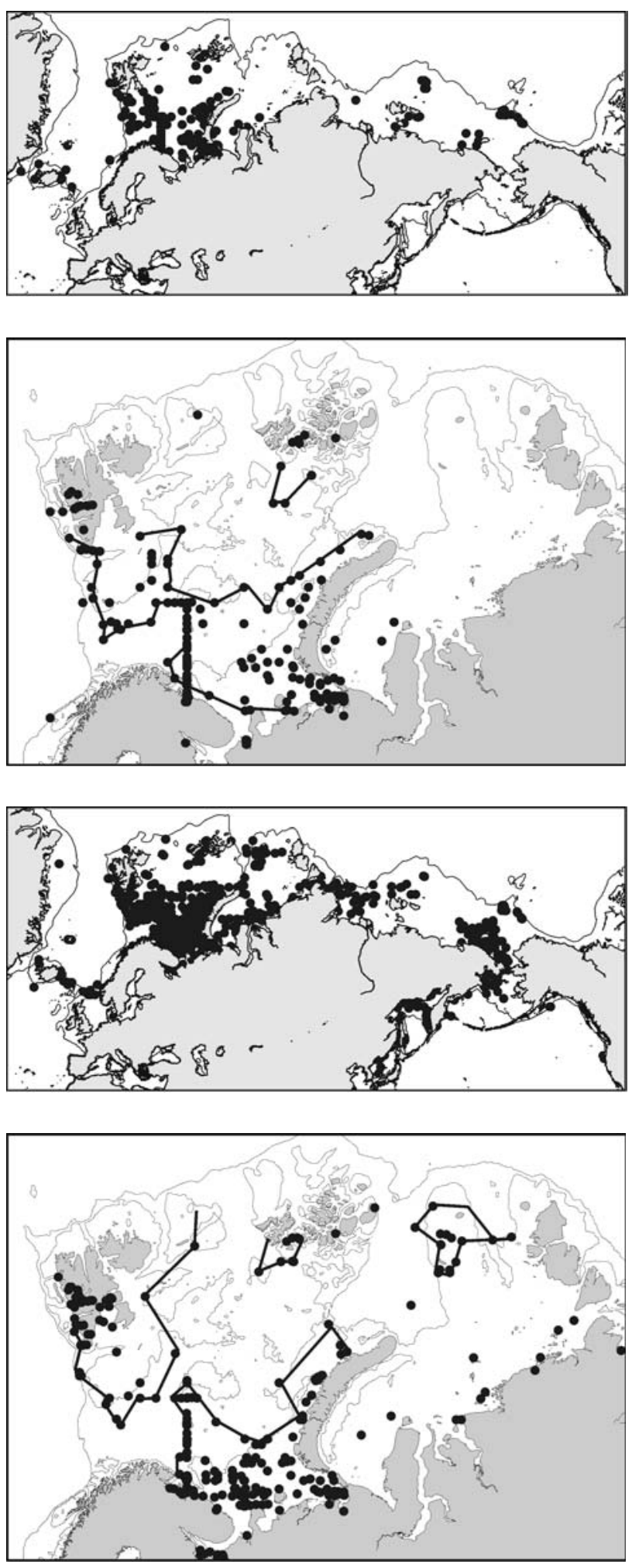

Fig. 9. The range of Arctic shelf species. Shown are 385 findings of Paranaitis wahlbergi, Brada rugosa, B. streltzovi, Clymenura polaris, Owenia polaris, Ampharete borealis, Amphicteis sundevalli, Branchiomma arctica, Euchone papillosa. $500-\mathrm{m}$ isobath is shown.

Рис. 9. Ареал арктических шельфовых видов.

Показаны 385 находок Paranaitis wahlbergi, Brada rugosa, B. streltzovi, Clymenura polaris, Owenia polaris, Ampharete borealis, Amphicteis sundevalli, Branchiomma arctica, Euchone papillosa. Показана 500-метровая изобата.

Fig. 10. Distribution of LSG-5 species with Arctic shelf range in the Barents Sea. Shown are 286 findings of the same species as in Fig. 9. 200- and 600-m isobaths are shown. Рис. 10. Распространение LSG-5 видов с арктическим шельфовым ареалом в Баренцевом море.

Показаны 286 находок тех же видов, что и на рис. 9. Показаны 200- и 600-метровые изобаты.

Fig. 11. The range of Arctic-Pacificboreal shelf species.

Shown are 1744 findings of Pectinaria hyperborea, Ampharete finmarchica, Lysippe labiata, Axionice flexuosa, Lanassa nordenskjoldi, Leaena ebranchiata. 500-m isobath is shown.

Рис. 11. Ареал аркто-тихоокеанских шельфовых видов.

Показаны 1744 находки of Pectinaria hyperborea, Ampharete finmarchica, Lysippe labiata, Axionice flexuosa, Lanassa nordenskjoldi, Leaena ebranchiata. Показана 500метровая изобата.

Fig. 12. Distribution of LSG-5 species with Arctic-Pacific-boreal shelf range in the Barents Sea.

Shown are 1383 findings of the same species as in Fig. 11. 200- and 600-m isobaths are shown.

Рис. 12. Распространение LSG-5 видов с аркто-тихоокеанским шельфовым ареалом в Баренцевом море.

Показаны 1383 находки тех же видов, что и на рис. 11 . Показаны $200-$ и 600 -метровые изобаты. 
Fig. 13. Distribution of LSG-6 species in the Barents Sea.

Shown are 53 findings of Melinnopsis arctica and Hyalopomatus claparedii. $300-\mathrm{m}$ isobath is shown.

Рис. 13. Распространение LSG-6 видов в Баренцевом море.

Показаны 53 находки Melinnopsis arctica и Hyalopomatus claparedii. Показана 300метровая изобата.

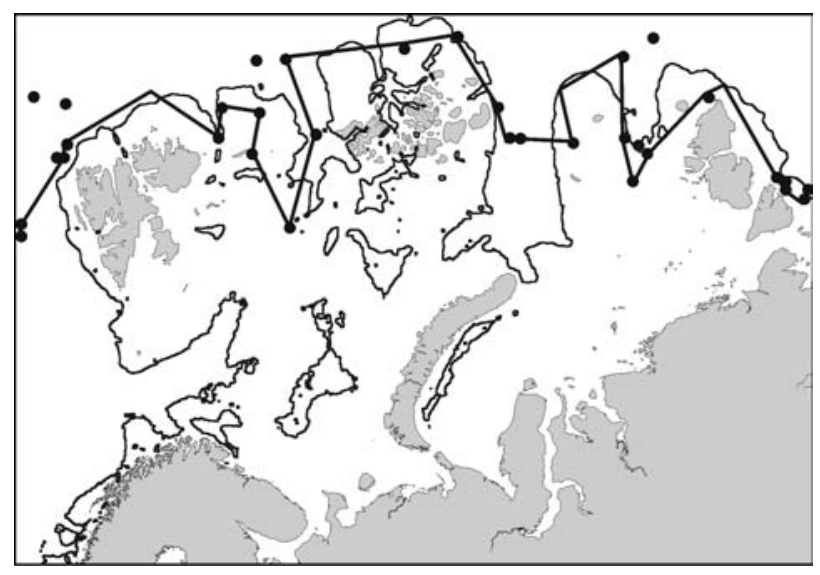

LSG-3. Species distributed in southwestern part of the sea outside tidally mixed regions (Fig. 7), some of them can be also distributed in tidally mixed regions.

LSG-4. Species living both in the southwest and in the southeastern part of the sea, towards the Kara Sea (Fig. 8).

LSG-5. Species absent in the southwestern part of the Sea (refuges in inlets, bays and fjords excepted). This group includes besides arctic species (Fig. 9) species distributed in the Pacific, towards Peter the Great Bay in the Japan Sea (Fig. 11) as well. The last group inclides such very common in the Barents Sea species as Pectinaria hyperborea and Ampharete finmarchica. The former is even one of the most abundant species of the whole marcobenthos (not only Polychaeta) (Brotskaja, Zenkevitch, 1939). Both groups inhabit in Atlantic part of the Newfounland region, which is the part of Arctic (see for example Nesis, 1982).

However, distribution of both groups in the Barents Sea is much the same (Figs 11 and 12), both these groups have similar western and northern synperates in the Barents Sea and therefore there are no grounds to treat them as different LSGs. LSG-5 is absent in the northeastern part of the Sea, appearing again only in shallowwater area off Franz Josef Land.

In the south-western part of the sea (westward of the Kola meridian, $33^{\circ} 30^{\prime} \mathrm{E}$ ), the distributions of LSG-3 and LSG-4 are complementary to that of LSG-5. Starting from the Kola merid- ian, the distributions of LSG-3 and LSG-4 differ: the LSG-3 synperate passes southward along the Kola meridian and only, in the very coastal areas, curves eastward, entering the White Sea, but not occurring off the eastern shores of the White Sea funnel. The synperate of LSG-4 species deviates eastward of the Kola meridian at about $72^{\circ} \mathrm{N}$, and forms tongues westwards to Novaya Zemlya between $200 \mathrm{~m}$ isobath and coast, and the second between mainland and 50 $\mathrm{m}$ isobath at about $69^{\circ} \mathrm{N}$, towards the Kara Sea. LSG-4 species were recorded in the northeastern Barents and northern Kara seas. This distribution cannot be due to larval migration, since it occurs also for species lacking a pelagic larva, e.g. Sosane wireni. These isolated areas may be considered as refuges warmed by Atlantic water passing beneath the freshened surface lens.

LSG-6 occurs only in the northern Barents Sea, almost exclusively at depths exceeding 300 $\mathrm{m}$ (Fig. 13). This LSG includes two high-Arctic deep-sea species: Melinnopsis arctica and $\mathrm{Hy}$ alopomatus claparedi (Jirkov, 2001).

LSG-7 is widely distributed in the Barents Sea at depths of $300 \mathrm{~m}$ and more (Fig. 14). This LSG includes species widely distributed in both the Atlantic and Pacific and the Arctic Notoproctus oculatus, Glyphanostomum pallescens and Samythella elongata, the Arctic endemics Maldane arctica, Amage auricula, Amphicteis ninonae, and Protula globifera. They are absent in the most south-east part of the Sea and in Spitsbergen-Bear Island plateau (but can be 

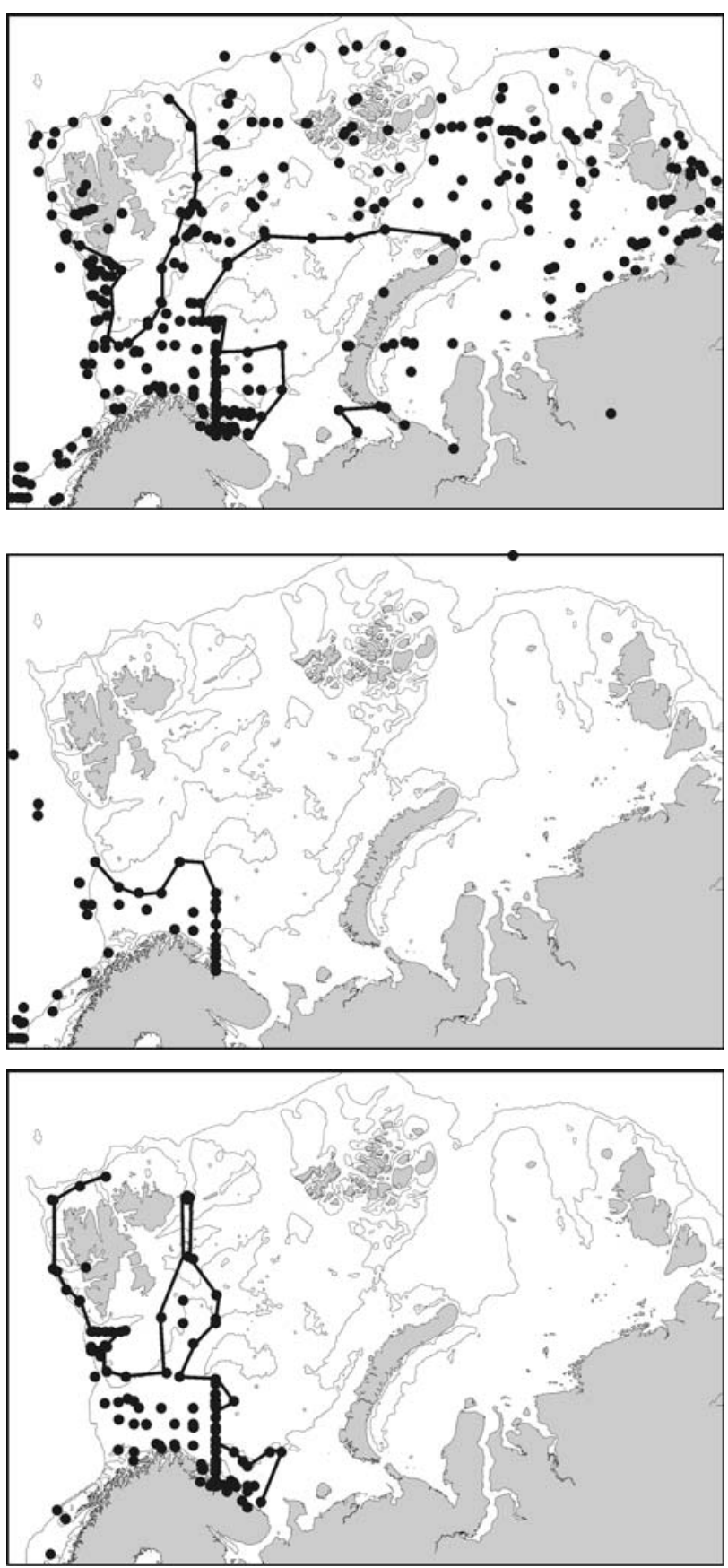

Fig. 14. Distribution of LSG-7 species in the Barents Sea.

Shown are 956 findings of Maldane arctica, Notoproctus oculatus, Amage auricula, Amphicteis ninonae, Glyphanostomum pallescens, Samythella elongata, Protula globifera. 200- and 600-m isobaths are shown.

Рис. 14. Распространение LSG-7 видов в Баренцевом море.

Показаны 956 находок Maldane arctica, Notoproctus oculatus, Amage auricula, Amphicteis ninonae, Glyphanostomum pallescens, Samythella elongata, Protula globifera. Показаны 200- и 600-метровые изобаты.

Fig. 15. Distribution of LSG-8 species in the Barents Sea.

Shown are 65 findings of Nicomache quadrispinata, Anobothrus laubieri, Jasmineira schaudinni. 200- and $600-\mathrm{m}$ isobaths are shown.

Рис. 15. Распространение LSG-8 видов в Баренцевом море.

Показаны 65 находок Nicomache quadrispinata, Anobothrus laubieri, Jasmineira schaudinni. Показаны 200- и 600-метровые изобаты.

Fig. 16. Distribution of LSG-9 species in the Barents Sea.

Shown are 253 findings of Asychis biceps and Potamilla neglecta. 200- and 600-m isobaths are shown.

Рис. 16. Распространение LSG-9 видов в Баренцевом море.

Показаны 253 находок Asychis biceps и Potamilla neglecta. Показаны 200- и 600метровые изобаты. found within Spitsbergen and Franz-Joseph Land archipelags). The synperate between LSG-7 and LSG-5 going eastward from $35^{\circ} \mathrm{E}$ mainly along $77^{\circ} 30^{\prime}$.
LSG-8 is found only in troughs in the southwest of the sea (Fig. 15). At the middle-scale, its distribution within the Barents Sea is very similar to that of LSG-3. The only difference is that 
species of LSG-3 were not recorded in most of the Medvezhij Island trough. However, while the species range borders in the south-west Barents Sea are the eastern ones (or, at least, the borders of the near-Atlantic part of species ranges) in all species of LSG-3, LSG-8 comprises species with completely different species ranges, they are exclusively endemics of the North Polar Basin: Nicomache quadrispinata, Anobothrus laubieri and Jasmineira schaudinni. A similar species range borders are characteristic for deep-sea species of echinoderms including the endemic Arctic sea lily Poliometra prolixa and occurring also in the Atlantic sea stars Korethraster hispidus and Solaster squamatus (Shorygin, 1928).

LSG-9 comprises species that were found, like LSG-8, only in troughs of the southwest of the sea but also in the trough passing east of Spitsbergen (a continuation of the Medvezhij Island trough) (Fig. 16). Paradoxically, this LSG includes also species with the main part of their range situated south of the range of the LSG-8. The Barents Sea synperate of LSG-9 is the eastern range borders in the Atlantic sector of the North Polar Basin of two boreal species, Asychis biceps and Potamilla neglecta.

The nine LSGs correspond to eight synperates, since LSG-1 has no synperate within the Barents Sea. Synperate LSG-2 delineates the biogeographical region inhabited by upper-sublittoral biota. Five or six synperates in the southwestern part of the sea form an aggregation zone that can be called the "zone of crowding of the synperates", similar to the the "zone of crowding of the species range limits". This belt passes from Medvezhij Island to the Central Rise and then moves southward along, approximately, the Kola meridian. Some synperates almost reach the shore, where they curve eastward along the coast.

Two synperates curve eastward far from the coast passing about along the 100-m isobath of the south-eastern part of the Sea, whereas the third one forms a tongue along the southern island of Novaya Zemlya, approximately along the isobaths of 100 and $200 \mathrm{~m}$, and rounding it to the south, enters shallow water.
Thus synperates form "a crowding zone" in the south-west corner of the Barents Sea. Can this the zone of synperate crowding be accepted as boundary of Arctic? Really, the "Arctic" edge of this zone more or less corresponds to the boundary between the Arctic and boreal regions of Golikov (1963, 1980), Kussakin (1979) and Briggs (1995), whereas the "boreal" edge corresponds to the same boundary of Zenkevitch (1947) and Gurjanova (1951). The border of Nesis (1982) is situated further northward and corresponds rather to the border of Filatova (1957) between low- and high-Arctic regions, and to the synperate LSG-7.

However the zone of synperate crowding does not actually correspond to the boundary between Arctic and boreal regions. The distribution of eurybathic Arctic endemics (LSG-8) in the south-western Barents Sea is complementary to that of stenobathic shelf endemics (LSG5). Using the terminology in Sirenko et al. (2009) (see Table 1), it can be said that the southwestern species range boundary of some Arctic species is the northeastern species range boundary of other Arctic species. But these arctic species in reality have different species ranges. The former species are the shelf ones, while the last species are the eurybathyc ones.

\section{Resulting scheme of biogeographi- cal regionalization of the Barents Sea}

In summary: the following provinces can be recognised in the Barents Sea (Fig. 17):

1. Scandinavian shallow-water.

2. Near-Atlantic shelf.

3. Low Arctic west.

4. Low Arctic east.

5. North Polar (High Arctic) shelf.

6. Sublittoral-upper-bathyal North Polar.

7. Deep-sea North Polar.

The first two and fifth are shallow-water and belong to the Arctic-Boreal Shelf Region. There is no reason to take the North Polar shelf province as a region of high rank, contrast to all boreal regions, as has been done by some authors (Gurjanova, 1972), because the bulk of North Polar shelf province fauna is composed of 


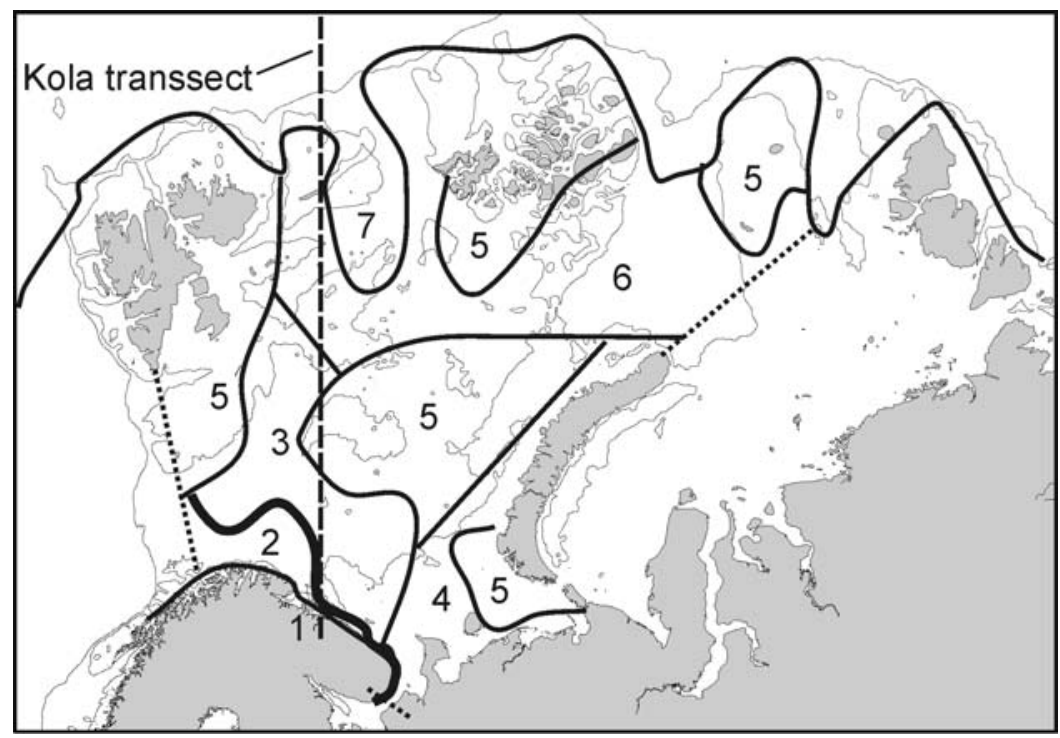

Fig. 17. Resulting scheme of biogeographical regionalization of the Barents Sea.

Provinces: 1 - Scandinavian shallow-water; 2 - Near-Atlantic shelf; 3 - Low Arctic west; 4 - Low Arctic east; 5 - North Polar shelf; 6 - Lower sublittoral-upper-bathyal North Polar; 7 - Deep-sea North Polar. Dotted lines show borders of investigated areas. 200- and 600-m isobaths are shown.Bold line - Arctic-Boreal boundary.

Рис. 17. Итоговая схема биогеографического районирования Баренцева моря.

Провинции: 1 - Скандинавская мелководная; 2 - Приатлантическая шельфовая; 3 - Низкоарктическая западная; 4 - Низкоарктическая восточная; 5 - Северо-полярная шельфовая; 6 - Нижнесублиторальноверхнебатиальная Северополярная; 7 - Глубоководная Северополярная. Исследуемый район ограничен точечными линиями. Показаны 200- и 600-метровые изобаты. Жирная линия - Аркто-Бореальная граница.

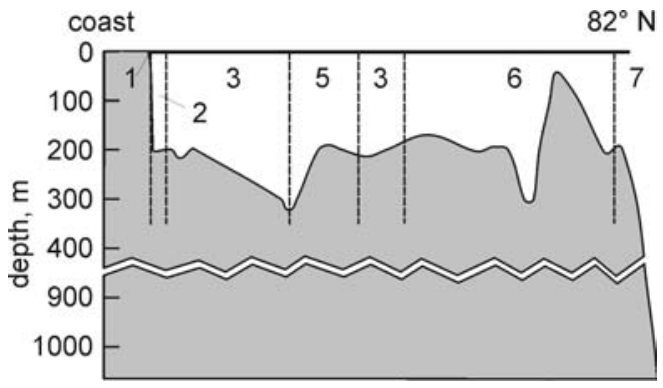

Fig. 18. The Kola transsect $\left(33^{\circ} 30^{\prime} \mathrm{E}\right)$ from coast to $82^{\circ} \mathrm{N}$.

Numbers are the same as in Fig. 17.

Рис. 18. Разрез вдоль Кольского меридиана $\left(33^{\circ} 30^{\prime} \mathrm{E}\right)$ от берега до $82^{\circ} \mathrm{N}$.

Числа те же, что и на рис. 17.

species with ranges embracing at least one of boreal shelf region as well. The position of the Deep-sea North Polar and Sublittoral-upperbathyal North Polar provinces within global scheme of biogeography can be shown only after arrangement of an integrated biogeogra- phical scheme of the World Ocean, including all depths from intertidal to abyssal. At present time it is not possible to state if the bathyal Provinces are a part of deep or shallow water ones. The final decision can be made only after making a scheme for all depths. However already now it can be state that the depth by itself is not the most important factor, determinative for the positions of biogeographic borders. Transect placed across the Barents Sea along $33^{\circ} 30^{\prime}$ (Fig. 18) shows that last three provinces are placed at similar depth. However their faunas differ by species with different vertical distribution.

\section{Arctic-Boreal boundary}

Most authors dealing with the regionalization of the Barents Sea drew a boundary between Arctic and boreal regions. Few authors isolated deep-sea regions in the Barents Sea, although the fact of eurybathic, but mainly deep- 


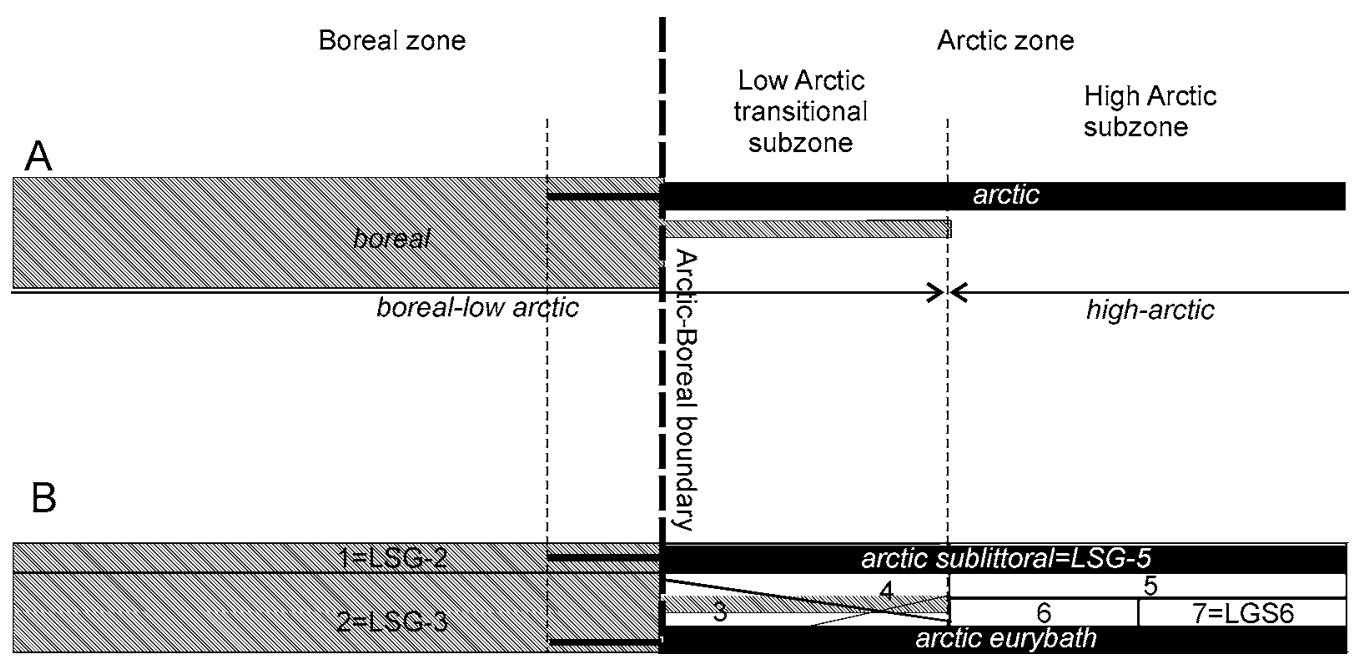

Fig. 19. Scheme of distribution of local species groups (LSGs) in the Barents Sea in relation to boreal and Arctic zones.

A - a situation within one vertical zone; B - a situation within the Barents Sea. Different types of species ranges are shown in italic. Width of the horizontal bands reflects number of species with certain type of distribution. Numbers are the same as in Fig 17.

Рис. 19. Схема распространения местных групп видов (LSGs) в Баренцевом море относительно к границе бореальной и Арктической зон.

А - схема в пределах одной вертикальной зоны; В - схема ситуации, имеющей место в Баренцевом море. Названия различных типов ареалов даны курсивом. Ширина горизонтальных полос отражает число видов с данным типом распространения. Цифры те же, что и на рис. 17.

sea species penetration into the Barents Sea has been known for a long time. Shorygin (1928: 106) wrote: [Abyssal part of the fauna undoubtedly reached the Barents Sea from the north]. Filatova (1957) recognised a "Eurasian marine bathyal province" within the Barents Sea as a part of the Arctic Region, the boundary of this Province coincided well with most part of the LSG-8 synperate. Anisimova (2000) recognized the "Central Barents Sea deep-sea region"; the borders of this region do not coincide with those of any previously isolated region. All species of LSG-6, LSG-7, LSG-8 and LSG-9 are much more abundant on the slope of the Arctic than on its shelf, and their synperates can be interpreted as a boundary of penetration of the deep-sea biota onto the Barents Sea shelf. An analysis of species distribution at a large scale shows that the problem of biogeographical regionalization of the Barents Sea cannot be reduced to a simple task of drawing a boundary between boreal and Arctic areas, northern and eastern for boreal species and southern and western for Arctic ones. More than a simple replacement of boreal for Arctic species occurs here. This, in my opinion, indicates that the conventional opinion of the Barents Sea as a sublittoral region is not reasonable. The Barents Sea also harbours a biogeographical boundary where occurs changes of shelf biota to the shallow-water one and shelf to the more deep water one. Probably the differences in understanding of the Barents Sea's biogeography are explained not only by different methodological approaches, but also by more complex biogeographical pattern of the sea.

In the southwestern part, the distribution of eurybathic Arctic endemics, comprising LSG-7 and LSG-8, is complementary to that of stenobathic shelf endemics (LSG-5). Eurybathic endemics of the Arctic, and more widely distributed species from LSG-7, LSG-8 and LSG-9, have species range borders coinciding in southwest part of the sea, and only northward of Central Rise does the difference in their species 
range borders becomes significant. Seemingly, synperates LSG-7, LSG-8 and LSG-9 outline the area of the penetration of eurybathic species into the Barents Sea. And the real pattern of species distribution greatly differs from the simple scheme dividing the Barents Sea into Arctic and boreal sublittoral regions (Fig. 1).

In reality schemes, like shown on Fig. 1 take places seldom. Usually some species cross the boundary. Belonging of these regions can be determined on the base of calculating number of species crossing and not crossing the boundary. If one geographic element prevails in number of species such region should be combine with regions inhabiting by the same geographic element only. If both (or more) geographic elements occurs in similar number of species such regions can be considered as transitional (Fig. 19A). Usually prevalence in number of species coincide with prevalence in biomasses. If regional fauna includes many species of one geographic element and few of other one the region to be treat as a part of the former region.

For example fauna of upper sublitoral of the Murman coast includes numerous boreal species and should be included in the Scandinavian shallow-water Province, despite very few arctic species, such as Ampharete vega inhabits it. On the other hand faunas of Low Arctic (or "Subartic" depending on taste) east and west regions includes a number of boreal species alongside with almost all Arctic species. So I prefer to take these regions as low Arctic, while no more northern regions can be called "high Arctic" (Fig. 19A).

Arctic-Boreal boundary is accepted here as the line of the greatest change in faunal composition between species with northern (Arctic) and more southern (Boreal) ranges (Fig. 17, bold line). The situation is sketchy reflected in Fig. 19B.

Two low arctic (transitional) provinces are of different nature. Biota of the Low Arctic west includes many eurybath species, arctic endemics, atlantic, and inhabiting Atlantic and Pacific as well. Biota of Low Arctic east on the other hand includes many boreal shelf species. In terms of vertical zonation the former seems more bathyal while the last more sublittoral.

Although the suggested scheme reflects only polychaete distribution, chorological analysis of other taxa is expected to show the same biogeographical pattern.

The real biogeographical pattern of the Sea is probably even more complex, especially regarding the Near-Atlantic shelf and Low Arctic Provinces. Based on our analysis, there occurs a complex mosaic of areas with Atlantic shelf biota and those with biota comprised of eurybathic species, both widely distributed and boreal and those endemic to the Arctic.

The true biogeography of the Barents Sea can only be mapped after an even more detailed analysis. Many more samples are needed to refine the biogeographic boundaries beyond the accuracy of 15-30 miles that was possible while data have been collected.

\section{Acknowledgements}

I am sincerely grateful to A.N. Mironov for his enormous effort and time spent for discussing and editing this paper. I am also indebted to B.I. Sirenko for the possibility to study Arctic polychaetes in the Zoological Institute, St.Petersburg. Dr. E.A. Frolova for possibility to use data from the collection of MMBI. A special thanks to Emma Delduca (MES Ltd., UK), who corrected my English. This work is part of the project "Arctic marine fauna: data accumulated in Russia" (sub-project of the CoML "Arctic Ocean Diversity" program).

\section{References}

Alekseev A.P., Galkin Yu.I. 1981. Otechestvennye issledovaniya bentosa v moryakh Severnogo Ledovitogo Okeana [Russian investigations of the benthos in the Arctic seas // Ocherki po istorii gidrobiologicheskikh issledovaniy v SSSR [Essays on history of hydrobiological investigations in the USSR]. Moscow: Nauka. P.41-60 [in Russian].

Anisimova N.A. 1989. Distribution patterns of echinoderms in the Eurasian sector of the Arctic Ocean // Y. Herman (ed.). The Arctic Seas. New York: Van Nostrand. P.281-301.

Anisimova N.A. 2000. [Echinoderms of the Barents Sea. Biogeographical analysis of the fauna] // G.G. Matishov (ed.). Sovremennyi bentos Barentsova i Karskogo morei [Current Benthos of the Barents and the Kara seas]. Apatity: Kola Science Centre RAS. P.237255 [in Russian, English abstract]. 
Beklemishev K.V. 1969. Ecologiya i biogeographiya pelagiali [Ecology and biogeography of the pelagial]. Moscow: Nauka. 291 p. [in Russian].

Briggs J.C. 1974. Marine Zoogeography. New York: McGraw-Hill Book Co. 475 p.

Briggs J.C. 1995. Global Biogeography. Amsterdam: Elsevier. 452 p.

Brotskaja V.A., Zenkevitch L.A. 1939. [N8. Quantitative data on bottom fauna of the Barents Sea] // Trudy Vsesoyuznogo nauchno-issledovatelskogo instituta morskogo rybnogo hozjaystva i okeanographii [Transactions of Russian Federal Research Institute of Fisheries and Oceanography]. Vol.4. P.5-126 [in Russian].

Dana J.D. 1853. On the classification and geographical distribution of crustacea; from the report on crustacea of the United States exploring expedition, under Captain Charles Wilkes, U.S.N., during the years 18381842. Philadelphia: Sherman. P.1393-1592.

Derjugin K.M. 1915. [Fauna of the Kola Bay and the conditions of its existence] // Zapiski imperatorskoj Akademii nauk po fiziko-matematicheskomu otdeleniju [Mémoires de l'Acadedémie Impériale des Sciences de Petrograd. VIII. Série, Classe Physico-mathétique]. Vol.34. No.1. 929 p.

Dice L.R. 1943. The biotic provinces of North America. Michigan: Univ. Mich. Press, Ann. Arbor. 78 p.

Ekman S. 1953. Zoogeography of the sea. London: Sidgwick and Jackson. 417 p.

Filatova Z.A. 1938. [Quantitative data on bottom fauna of the south-western Barents Sea]//Trudy PINRO [Transactions of Polar Research Institute of Marine Fisheries and Oceanography]. Vol.2. P.3-56 [in Russian].

Filatova Z.A. 1957. [Zoogeographical division of northern seas (by distribution of Bivalvia)] // Trudy Instituta Okeanologii [Transactions of the Institute of Oceanology]. Vol.23. P.195-215 [in Russian].

Forbes E. 1856. Map of the distribution of marine life, illustrated chiefly by fishes, molluses and radiata; showing also the extend and limits of the homoiozoic belts // A.K. Johnston (ed.). The physical atlas of natural phenomena, pl, 31. Edinburg, London: W. a. A.K. Johnston.

Golikov A.N. 1963. [Gastropoda of the genus Neptunea Bolten] // Fauna SSSR, Novaya Seriya [Fauna of the USSR. New series]. Is.85. Mollusca. Vol.5. No.1. P.1-218 [in Russian].

Golikov A.N. 1980. [Mollusca Buccininae of the World Ocean] // Fauna SSSR, Novaya Seriya [Fauna of the USSR. New series]. Is.121. Mollusca. Vol.5. No.2. P.1-508 [in Russian].

Golikov A.N., Scarlato O.A. 1989. Evolution of Arctic ecosystem during the Neogene period // Y. Herman (ed.). The Arctic Seas, New York: Van Nostrand. P.257-279.

Gurjanova E.F. 1951. [Side-swimmers of the Seas of the USSR and adjacent waters (Amphipoda-Gammaridea)] // Opredeliteli po faune SSSR [Keys to the fauna of the USSR]. Leningrad. Vol.41. P.1-1029 [in Russian].
Gurjanova E.F. 1957. [Towards zoogeography of the Arctic Basin] // Materiali nabludenij nauchno-issledovatelskih dreifujushih stantsiy"Severnij Polus-3" y "Severnij Polus-4" 1954/55 goda [Materials of scientific research drifting station "Severnij Polus-3" and "Severnij Polus-4" 1954/55 years]. Vol.1. P.343-355 [in Russian].

Herman Y. 1989 (ed.). The Arctic Seas - climatology, oceanography, geology, and biology. New York: Van Nostrand Reinhold Co. 888 p.

Jirkov I.A. 2001. Polichety severnogo Ledovitogo okeana [Polychaeta of the Arctic Ocean]. Moscow: Yanus-K Press. 632 p. [in Russian].

Jirkov I.A. 2004. [About a technique of realization of the biogeographical bondaries] // A.I. Kafanov (ed.). Obschie voprosy morskoj biogeografii: pamjaty akademika O.G. Kusakina [Main problem in marine biogeography: in memory of the academician O.G. Kussakin]. Vladivostok: Dalnauka. P.98-111 [in Russian, English summary].

Kafanov A.I., Kussakin O.G., Nesis K.N., Skarlato O.A., Starobogatov Ya.I. 1980. Proyekt kodeksa terminologii i nomenklatury edinits rayonirovaniya $\mathrm{v}$ morskoy biogeografii [Draft of code of terminology and nomenclature marine biogeographic units]. Vladivostok: Far-Eastern Scientific center of Academy of Science of the USSR. 24 p. [in Russian].

Khlebovich V.V. 1996. [Polychaetes of the family Nereididae of the Russian seas and the adjacent waters] // Fauna Rossii i sopredelnih stran. Novaya Seriya [Fauna of the Russia and neigbouring countries. New series]. Is.140. Polychaeta. Vol.3. P.1-223 [in Russian].

Kiseleva K.V. et al. 1969. [Borders of plant communities and vegetation dynamic] // Zhurnal obshej biologii [Journal of General Biology]. Vol.30. No.2. P.123131 [in Russian].

Kupriyanova E.K., Jirkov I.A. 1997. Serpulidae (Annelida, Polychaeta) of the Arctic Ocean // Sarsia. Vol.82. No.6. P.203-236.

Matishov G.G. 2000 (ed.). [Current Benthos of the Barents and the Kara Seas]. Apatity: Kola Science Centre RAS. 486 p. [in Russian].

Matjushkin E.N. 1972. [Heterogeneity of Ussury region theriofauna: common characters, origin and contemporary display in Middle Sihote-Alin communities] // Trudy Zoologicheskogo Muzeya MGU [Archives of Zoological Museum of Moscow State University]. Vol.13. P.86-144 [in Russian].

Menzies R.J., George R.Y., Rowe G.T. 1973. Abyssal environment and ecology of the World Ocean. New York: John Wiley. 488 p.

Nesis K.N. 1982. [Zoogeography of the World Ocean: comparison of zonation of the pelagic realm and regional subdivision of the shelf (concerning cephalopods)] // O.G. Kussakin (ed.). Morskaya biogeographiya. Predmet, metody, printsipy rayonirovaniya [Marine biogeography: Subject, methods, and principles of regionalization]. Moscow: Nauka Press. P.114134 [in Russian]. 
Nesis K.N. 1987. [Cephalopods of the Arctic Ocean and its seas] // A.I. Kafanov (ed.). Fauna and distribution of mollusks: North Pacific and Polar Basin. Vladivostok: Far Eastern Science Center of USSR Academy of Science. P.115-136 [in Russian].

Ortmann A.E. 1896. Grundzüge der marinen Tiergeographie. Jena: G. Fisher. 96 S.

Petryashov V.V. 1989. Arctic Ocean mysids (Crustacea: Mysidacea): evolution, composition, and distribution // Y. Herman (ed.). The Arctic Seas New York: Van Nostrand. P.373-396.

Petryashov V.V. 2009. The Biogeographical Division of the Arctic and North Atlantic by the Mysid (Crustacea: Mysidacea) Fauna // Russian Journal of Marine Biology. Vol.35. No.2. P.97-116. [Original Russian Text Petryashov V.V. 2009, published in Biologiya Morya.]

Razumovsky S.M. 1999. [Introduction to the geography of contemporary plants] // Razumovsky S.M. Izbrannie trudy [Selected works]. Moscow: KMK Scientific Press. P.19-118 [in Russian].

Schmarda L.K. 1853. Die geographische Verbreitung der Tiere. Abth. I-III, Wien: Gerold und Sohn.

Schmidt P.Yu. 1904. [Fishes of the eastern seas of the Russian Empire]. St.-Petersburg: Stasyulevich Press. $\mathrm{XI}+466$ p. [in Russian].

Shorygin A.A. 1928. [Die Echinodermen des Barentsmeeres] // Trudy morskogo nauchnogo instituta [Berichte des Wissenschaftlichen Meeresinstituts]. Vol.3. No.4. P.1-128 [in Russian, German summary].

Stegman B.K. 1938. [Fundamentals of ornitogeographic subdivision of Palearctic] // Fauna SSSR. Novaya Seriya [Fauna of the USSR. New series]. Is.19. Aves. Vol.1. No.2. P.1-157 [in Russian].

Sirenko B.I., Vassilenko S.V., Petryashov V.V. 2009. Distribution patterns for shelf species of Eurasian Arctic seas // S.V. Vassilenko, V.V. Petryashov (eds.). Illustrated keys to Free-Living Invertebrates of Eurasian Arctic Seas and Adjacent Deep Waters. Fairbanks: Alaska Sea Grant, University of Alaska Fairbanks. Vol. I. Rotifera, Pycnogonida, Cirripedia, Leptostraca, Mysidacea, Heperiidea, Caprellidea, Euphausiacea, Dendrobranchiata, Pleocyemata, Anomura, and Brachyura. P.179-186.
Tolmachev A.I. 1962. Osnovi ucheniya ob arealakh [Fundamentals of species range doctrine]. Leningrad: Leningrad University Press. 100 p. [in Russian].

Tupikova N.V., Komarova L.V. 1979. Printzipy y metody zoologicheskogo kartografirovaniya [Principles and methods of zoological mapping]. Moscow: Moscow State University Press. 192 p. [in Russian].

Uschakov P.V. 1972. [Polychaetes of the suborder Phyllodociformia of the Arctic Ocean and the northwestern part of the Pacific Ocean (families Phyllodocidae, Alciopidae, Tomopteridae, Thyphloscolecidae and Lacidoniidae)] // Fauna SSSR. Novaya Seriya [Fauna of the USSR. New series]. Is.102. Polychaeta. Vol.1. P.1-272 [in Russian].

Uschakov P.V. 1982. Polychaetes of the suborder Aphroditiformia of the Arctic Ocean and the northwestern part of the Pacific Ocean. Families Aphroditidae and Polynoidae) // Fauna SSSR, Novaya Seriya [Fauna of the USSR. New series]. Is.126. Polychaeta. Vol.2. No.1. P.1-272 (Translated by National Museum Canada N 1112189, Nov. 30 1987).

Vinogradova N.G. 1977. [Fauna of the continental shelf and slope and abyssal] // M.E. Vinogradov (ed.). Okeanologiya. Biologiya okeana. 1. Biologicheskaya struktura okeana [Oceanology. Biology of the Ocean. 1. Biological Structure of the Ocean]. Moscow: Nauka Press. P.178-198 [in Russian].

Wikipedia http://ru.wikipedia.org/wiki/\%D0\%90\%D1\% $80 \% \mathrm{D} 0 \% \mathrm{BA} \% \mathrm{D} 1 \% 82 \% \mathrm{D} 0 \% \mathrm{~B} 8 \% \mathrm{D} 0 \% \mathrm{BA} \% \mathrm{D} 0 \% \mathrm{~B} 0$

Woodward S.P. 1856. A manual of the mollusca. London: John Weale. viii +486 p.

Zenkevitch L. 1946. [Fauna of the Sea] // N.A. Bobrinsky, L.A. Zenkevich, Ya.A. Birstein (eds.). Geografiya zhivotnykh. [Animal geography]. Moscow: Sovetskaya Nauka. P.92-223 [in Russian].

Zenkevitch L. 1947. Fauna i biologicheskaya produktivnost morya [Fauna and biological productivity of the Sea]. Leningrad: Sovetskaya Nauka. Vol.2. 588 p. [in Russian].

Zenkevitch L. 1963. Biology of the seas of the U.S.S.R. London: George Allen \& Unwin Ltd. 955 p.

Zernov S.A. 1949. Obshchaya gidrobiologia. [General hydrobiology]. Second edition. Moscow-Leningrad: Izdatelstvo AN SSSR. 587 p. [in Russian]. 